\title{
Effect of Water Stress and Fungal Inoculation on Monoterpene Emission from an Historical and a New Pine Host of the Mountain Pine Beetle
}

\author{
Inka Lusebrink • Maya L. Evenden • \\ F. Guillaume Blanchet • Janice E. K. Cooke • \\ Nadir Erbilgin
}

Received: 19 May 2011 /Revised: 5 August 2011 /Accepted: 12 August 2011 /Published online: 27 August 2011

(C) Springer Science+Business Media, LLC 2011

\begin{abstract}
The mountain pine beetle (Dendroctonus ponderosae, MPB) has killed millions of lodgepole pine (Pinus contorta) trees in Western Canada, and recent range expansion has resulted in attack of jack pine (Pinus banksiana) in Alberta. Establishment of MPB in the Boreal forest will require use of jack pine under a suite of environmental conditions different from those it typically encounters in its native range. Lodgepole and jack pine seedlings were grown under controlled environment conditions and subjected to either water deficit or well watered conditions and inoculated with Grosmannia clavigera, a MPB fungal associate. Soil water content, photosynthesis, stomatal conductance, and emission of volatile organic compounds (VOCs) were monitored over the duration of the six-week study. Monoterpene content of bark and needle tissue was measured at the end of the experiment. $\beta$-Phellandrene, the major monoterpene in lodgepole pine, was almost completely lacking in the volatile emission profile of jack pine. The major compound in jack pine was $\alpha$-pinene. The emission of both compounds was positively correlated with stomatal conductance. 3-Carene was emitted
\end{abstract}

I. Lusebrink · M. L. Evenden · J. E. K. Cooke

Department of Biological Sciences, University of Alberta,

CW405 Biological Science Building,

Edmonton, Alberta T6G 2E9, Canada

F. G. Blanchet

Department of Renewable Resources, University of Alberta,

751 General Service Building,

Edmonton, Alberta T6G 2H1, Canada

I. Lusebrink $(\bowtie) \cdot N$. Erbilgin

Department of Renewable Resources, University of Alberta,

4-42 Earth Science Building,

Edmonton, Alberta T6G 2E3, Canada

e-mail: lusebrin@ualberta.ca at a high concentration from jack pine seedlings, which is in contrast to monoterpene profiles of jack pine from more southern and eastern parts of its range. Fungal inoculation caused a significant increase in total monoterpene emission in water deficit lodgepole pine seedlings right after its application. By 4 weeks into the experiment, water deficit seedlings of both species released significantly lower levels of total monoterpenes than well watered seedlings. Needle tissue contained lower total monoterpene content than bark. Generally, monoterpene tissue content increased over time independent from any treatment. The results suggest that monoterpenes that play a role in pine-MPB interactions differ between lodgepole and jack pine, and also that they are affected by water availability.

Key Words Pinus contorta Pinus banksiana . VOCs . Monoterpenes · Tree defense - Grosmannia clavigera . Mountain pine beetle

\section{Introduction}

The mountain pine beetle (MPB), Dendroctonus ponderosae Hopkins (Coleoptera: Curculionidae, Scolytinae) has destroyed 16.3 million ha of mainly lodgepole pine (Pinus contorta Dougl. ex Loud.) forests in British Columbia, Canada (www.for.gov.bc.ca) during the current outbreak, which began over a decade ago. In the last 5 years, MPB has moved eastward into Alberta, where in the northern part of the province the ranges of lodgepole pine and jack pine (Pinus banksiana Lamb.) overlap, resulting in a zone of hybridization (Cullingham et al., 2011). Lodgepole pine is one of the historical hosts of MPB in Western Canada, however, as its range expands from its historical habitat to 
new areas in northern Alberta (Carroll et al., 2006), MPB has spread across the lodgepole $\times$ jack pine hybrid zone into stands of pure jack pine (Cullingham et al., 2011). Studies show that beetles can reproduce and develop in jack pine (Cerezke, 1995), as do its fungal associates (Rice et al., 2007). Jack pine is the most abundant pine species in the boreal forest which potentially could lead to the spread of MPB across the boreal forest to eastern Canada.

Global climate change might allow MPB to expand its range into formerly unoccupied lodgepole pine habitat and also enable further eastward invasion of jack pine (Williams and Liebhold, 2002). Climate change is expected to produce longer and more frequent droughts in many regions of the world (Breshears et al., 2009) that may influence the ability of trees to defend themselves against invading insects and diseases (reviewed in Franceschi et al., 2005). For plant species that are conservative water users, prolonged droughts will decrease carbon dioxide uptake and associated photosynthetic carbon assimilation due to stomata closure. Reduced carbon gain can result in the depletion of carbohydrate reserves for biosynthesis of defensive compounds, particularly carbon-based compounds such as terpenoids that could make trees more susceptible to biotic stress factors, such as bark beetles (McDowell et al., 2008; Breshears et al., 2009). Water deficit is one of the climatic variables used in climate-suitability models for MPB populations; in these models, it reduces the resistance of lodgepole pine to attack and subsequent development and survival of the beetle (Safranyik et al., 2010).

Increasing temperature predicted under a global climate change scenario also could alter volatile emission by potential host trees, since monoterpene emission is temperature dependent (Kesselmeier and Staudt, 1999), and might influence host finding by MPB. Two mechanisms are proposed to explain host finding by pioneering MPB. Beetles could visually orient towards and randomly land on potential host trees and then use gustatory cues to assess the suitability of the host (Raffa and Berryman, 1982). Alternatively, recognition and direct flight towards a host could be based on orientation to volatile organic compounds (VOC) emitted from the host (Moeck and Simmons, 1991) in combination with visual cues. MPB is able to detect and avoid non-hosts, which supports the hypothesis of direct flight as a host finding mechanism (Huber et al., 2000). Both mechanisms might act together; differences in VOC emission from different host trees grown under different conditions and with different levels of beetle infestation may be an indication of host suitability to orienting beetles. Successful attack and colonization of the host may be further influenced by the chemical composition of the bark of the host tree (Faccoli et al., 2005; Raffa et al., 2005).

Once a suitable host is found by a female pioneer beetle, $\alpha$-pinene-one of the most abundant host monoterpenes in most pine species examined to date-is hydroxylated into the major aggregation pheromone trans-verbenol that attracts both sexes of MPB to initiate a mass attack (Pitman et al., 1968; Blomquist et al., 2010). As the colonization progresses, arriving males produce exo-brevicomin that attracts additional females until the optimum attack density is achieved, at which point both male and female beetles emit anti-aggregation pheromones that prevent further recruitment to the host tree (Rudinsky et al., 1974; Ryker and Libbey, 1982).

At least two MPB associated blue stain fungi, Grosmannia clavigera and Ophiostoma montium, also deplete tree defenses and kill their host (Reid et al., 1967; Rice et al., 2007) during the host colonization process. Grosmannia clavigera is more virulent than $O$. montium (Yamaoka et al., 1990) and often is used experimentally to stimulate tree defenses (Reid et al., 1967; Lieutier et al., 2009).

Trees that are mass attacked by the bark beetle plus associated fungi are defended with resin, a mixture of monoterpenes, sesquiterpenes, diterpenoid resin acids, and phenolic compounds characteristic of conifers (Keeling and Bohlmann, 2006) that act as physical and chemical defenses. Resin monoterpene composition differs between species, and the composition of individual trees in various pine species correlates with resistance to bark beetle attack (Sturgeon, 1979; Gollob, 1980).

In order to test the hypothesis that tree responses differ between lodgepole and jack pine trees, and also are affected by environmental conditions, we conducted a controlled environment experiment on seedlings subjected to water deficit (simulating drought conditions) and used the MPB fungal associate Grosmannia clavigera in conjunction with wounding to stimulate tree defenses.

The objectives were to: (1) develop a chemical profile of volatiles released from the two different host tree species; (2) evaluate if volatile chemical profiles vary within and between tree species when subjected to different environmental (water deficit vs. well watered) and biological (fungal inoculation, mechanical wounding, and control) treatments; and (3) determine if the monoterpenoid content of tissues is affected by the treatments and differs between tree species.

\section{Methods and Materials}

Seedling Source and Treatments Seedlings in their second growth cycle were used for all experiments. Lodgepole pine (Pinus contorta var. latifolia Engelm. ex Wats.) originated from west-central Alberta, while jack pine was from provenances in north-central Saskatchewan. Seedlings were grown through their first growth cycle under near-identical conditions at PRT Vernon, then packaged and placed in cold storage for approximately 3 month to satisfy dormancy requirements. 
Dormant seedlings were shipped overnight to Edmonton, where $N=84$ seedlings per species were planted (pot size: $15 \times 18 \mathrm{~cm}$ ) in Sunshine Mix \#4 (Sungro, Vancouver BC Canada) and maintained throughout the experiment in a walkin growth chamber, with $16 \mathrm{~L} / 8 \mathrm{~h} \mathrm{D}, 200 \mu \mathrm{mol} \mathrm{m}{ }^{-2}$ full spectrum light intensity, $20^{\circ} \mathrm{C}$ constant temperature and approximately $50 \%$ humidity. Fertilizer was applied with irrigation weekly $(0.5 \mathrm{~g} / 120 \mathrm{~N}-20 \mathrm{P}-20 \mathrm{~K})$, with additional watering provided as necessary until 1 week before the start of the experiment at which point both species had completed shoot elongation with an average height of $21.5 \mathrm{~cm}( \pm 2.9$ S.D) for lodgepole pine and $32.5 \mathrm{~cm}$ ( \pm 4.0 S.D) for jack pine seedlings.

Once terminal bud formation had been initiated, seedlings of each species were randomly divided into two groups and received one of two water regimes: water deficit or well watered. Seedlings in the water deficit group received $50 \mathrm{ml}$ of water and those in the other group received $400 \mathrm{ml}$ twice a week for the duration of the 6-wk experiment. In order to ensure that the water deficit seedlings were experiencing mild water stress conditions at the onset of the 6-wk experiment, water was withheld from these seedlings prior to the application of the fungal treatments. Seedlings in both water treatment groups were assigned randomly to one of three treatments: (1) mechanical wounding plus inoculation with $G$. clavigera; (2) mechanical wounding alone; and (3) untreated control. The aim of the first treatment was to stimulate tree defenses with the MPB fungal associate, and the last two treatments were positive and negative control treatments, respectively. Seedlings were inoculated with $5 \mu$ l of a $G$. clavigera spore suspension injected into a pouch made with a 23G1 PrecisionGlide ${ }^{\mathrm{TM}}$ needle. The spore suspension was prepared by using a sterile inoculation loop and transferring two loopfuls $(20 \mu \mathrm{l})$ of spores of $G$. clavigera from a well sporulating strain collected from Fox Creek Alberta $\left(54^{\circ} 24^{\prime} \mathrm{N}\right.$, $\left.116^{\circ} 48^{\prime} \mathrm{W}\right)$ into sterile saline. Seedlings were inoculated at three points, equally distributed along the whole length of the stem. Mechanical wounding was applied in a similar manner but without the fungal inocula (Fig. 1).

For each tree species and water $\mathrm{x}$ biological treatment combination, four seedlings were randomly selected (total of 24 seedlings per species) and monitored for volatile emission, photosynthetic rate, stomatal conductance, and soil water content the day before inoculation $(t=0)$, and at five time points post inoculation ( $t=1$ day, $t=1$ week, $t=$ 2 week, $t=4$ week, and $t=6$ week). Twelve of the remaining seedlings of each treatment combination per species were destructively harvested at each time point $(N=2)$ for chemical analysis of the bark (primarily constituting phloem tissue) of the current year and previous growth of the stem (referred to as current year and previous year bark) and needles. After 6 week, we harvested the seedlings that were used for acquiring volatile emission and physiology data for tissue analyses (below).

Soil Water Content and Gas Exchange Parameters Soil water content was measured using time domain reflectrometry (TDR) (Hillel, 1998). We measured the apparent dielectric constant of the soil with a Tektronix 1502B (Beaverton, OR, USA) and used the empirical equation for organic soils in Robinson et al. (2003) to relate it to water content. Rate of photosynthesis and stomatal conductance were measured using a LI-6400 (LI-COR Biosciences, Lincoln, NE, USA). The instrument settings were: leaf area $1.5 \mathrm{~cm}^{2}$, flow $300 \mu \mathrm{mol} / \mathrm{sec}$, and Quantum flux lamp at $200 \mu \mathrm{mol} / \mathrm{m}^{2} \mathrm{sec}$ (equivalent to light intensity in growth chamber).

Volatile Collection Volatile organic compounds (VOCs) released from seedlings were collected 1 day after the physiological data were recorded from the same plant. An oven bag $\left(\mathrm{LOOK}^{\circledR}, 45 \times 55 \mathrm{~cm}\right)$ was imposed over the
Fig. 1 Methodology scheme showing the two different water treatments: water deficit and well watered, the three biological treatments: control, mechanical wounding and wounding plus inoculation with Grosmannia clavigera, and collection of VOCs
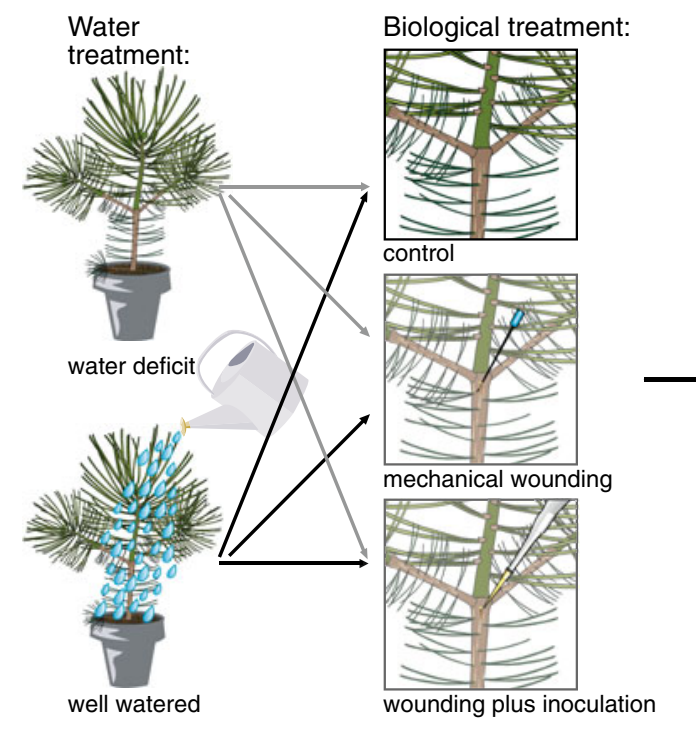

Volatile collection:

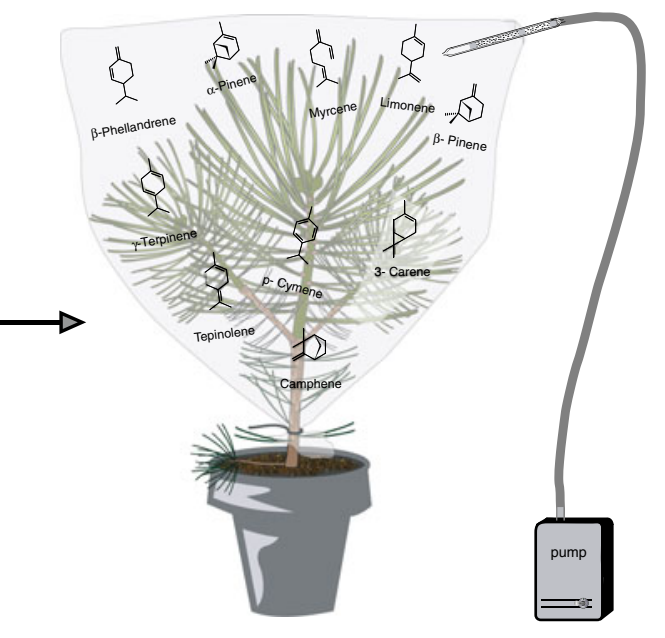


whole seedling and closed near the base of the stem with a cable tie. An absorbent tube [Porapak Q (OD $6 \mathrm{~mm}$, length $110 \mathrm{~mm}$; absorbent: front layer $150 \mathrm{mg}$, back up layer 75 mg; separated by glass wool) SKC Inc., PA, USA] was inserted into the bag at the top of the seedling and affixed with Parafilm ${ }^{\circledR}$. A small hole was placed on the other side of the oven bag to maintain constant air pressure inside the bag. Volatile emissions were collected for $4 \mathrm{~h}$ at a constant flow rate of $200 \mathrm{ml} / \mathrm{min}$. After collection, the sorbent tubes were capped and stored at $-40^{\circ} \mathrm{C}$ until extraction. Air samples were collected at two locations of the growth chamber to control for possibility of contamination with chamber air.

Porapak Q tubes were extracted with $1 \mathrm{ml}$ of dichloromethane (Sigma-Aldrich, St. Louis, MO, USA) spiked with $0.01 \%$ (v/v) tridecane (Sigma-Aldrich, St. Louis, MO, USA) as surrogate standard and subsequently stored at $-40^{\circ} \mathrm{C}$ before GC analysis.

Tissue Extracts Seedlings were harvested outside of the chamber in which VOCs were collected. During seedling harvest, bark and needle samples were frozen rapidly in liquid nitrogen, and stored at $-40^{\circ} \mathrm{C}$ prior to extraction. Tissue was ground in liquid nitrogen, and $100 \mathrm{mg}$ of the tissue were transferred to a $1.5 \mathrm{ml}$ microcentrifuge tube. Samples were extracted twice with $0.5 \mathrm{ml}$ dichloromethane and $0.01 \%$ tridecane as surrogate standard. After adding solvent, samples were vortexed for $30 \mathrm{sec}$, sonicated for $10 \mathrm{~min}$, subsequently centrifuged at $13,200 \mathrm{rpm}$ and $0^{\circ} \mathrm{C}$ for $15 \mathrm{~min}$, and placed in a freezer for at least $2 \mathrm{~h}$ to let the pellet freeze. Extracts were transferred into an amber GC vial and stored at $-40^{\circ} \mathrm{C}$ before $\mathrm{GC}$ analysis.

GC Analysis Samples $(1 \mu \mathrm{l})$ were injected in an Agilent 7890A Gas Chromatograph (Agilent Technologies, Santa Clara, CA, USA) with an HP Innowax (Agilent Technologies) column (I.D. $0.32 \mathrm{~mm}$, length $30 \mathrm{~m}$ ), helium carrier gas flow at $1.8 \mathrm{ml} / \mathrm{min}$, temperature $50^{\circ} \mathrm{C}$ for $2 \mathrm{~min}$, increased to $160^{\circ} \mathrm{C}$ by $5^{\circ} \mathrm{C}$ per min, and then to $250^{\circ} \mathrm{C}$ by $20^{\circ} \mathrm{C}$.

Peaks were identified using the following standards: Borneol, pulegone, $\alpha$-terpinene, $\gamma$-terpinene, $\alpha$-terpineol (Sigma-Aldrich, St. Louis, MO, USA), camphor, 3-carene, $\alpha$-humulene, terpinolene, $\alpha$-thujone and $\beta$-thujone, $(-)-\alpha-$ pinene, (-)- $\beta$-pinene, (S)-(-)-limonene, sabinene hydrate, myrcene, (-)-camphene, $p$-cymene (Fluka, Sigma-Aldrich, Buchs, Switzerland), bornyl acetate, cis-ocimene (SAFC Supply Solutions, St. Louis, MO, USA), $\beta$-phellandrene (Glidco Inc., Jacksonville, FL, USA).

Calibration with standards allowed for analysis of quantitative differences among samples of differently treated seedlings at different time points. For all samples, peaks were integrated and peak area was compared for qualitative and quantitative differences among samples of differently treated seedlings at different time points.
After all samples were analyzed with the GC, subsequent analysis with GC-mass spectrometry showed that our method was unable to separate myrcene and $\alpha$-phellandrene. From a different experiment, we know that $\alpha$-phellandrene hardly occurs in jack pine seedlings and makes up to $35 \%$ of the peak in lodgepole pine seedlings.

Statistical Analyses The VOC emission data and the seedling physiology data collected from the same trees were analyzed using the $\mathrm{R}$ statistical language ( $\mathrm{R}$ development core team, 2010). In order to address how volatile emission of the seedlings changed due to the environmental and biological treatments and their associated change in physiology, we carried out a canonical redundancy analysis (RDA; Legendre and Legendre, 1998) using the rdaTest package (Legendre and Durand, 2010). RDA axes were tested for significance by permutations with the vegan package (Oksanen et al., 2010) also through the R statistical language. Explanatory variables included water and biological treatments, as well as soil water content, photosynthesis and stomatal conductance. Total and individual monoterpenes of all time points were the response variables. Due to technical difficulties during the extraction process, two time points (weeks 1 and 6) were discarded from the jack pine dataset. In order to evaluate whether the resulting lack of correlation between soil water content and physiological parameters in jack pine was due to the missing two time points, we also carried out an RDA for lodgepole pine with the same time points omitted, the results remained the same.

To assess the effect of environmental treatments on total monoterpene emission from both tree species over time, Mann-Whitney $U$ tests were used. The effect of the biological treatments was assessed using repeated measures ANOVAs with subsequent pairwise comparison with Bonferroni correction on water deficit and well watered seedlings separately using SPSS Statistics 17.0. Soil water content and plant physiology results are presented using bar graphs with error bars showing $95 \%$ confidence intervals, non-overlapping bars represent a significant difference.

All tissue extract data were analyzed using SPSS Statistics 17.0. Total monoterpenes were analyzed using repeated measure ANOVA. Individual monoterpene data were transformed with $\log (\mathrm{x}+1)$ to meet the assumptions of normality and analyzed for all tissues separately using ANOVA. In cases in which the data violated the assumptions of an ANOVA, non parametric tests were conducted on non transformed data. Interspecific differences were analyzed using $t$-test.

\section{Results}

Soil Water Content and Gas Exchange Parameters The water deficit seedlings were not watered the week before 
the experiment started; therefore, there was a significant difference in soil water content between the well watered and water deficit seedlings on the first day of the experiment (Fig. 2). Through the duration of the experiment, the water content of the soil in the water deficit treatment decreased to almost $0 \%$, whereas soil water content of well watered seedlings stayed constant between $20 \%$ and $30 \%$.

Independent of the biological treatments, the photosynthesis rate in lodgepole pine decreased over time in the water deficit group, but not in the well watered group (Fig. 3a). In jack pine, neither the biological nor the water treatments had an effect on photosynthesis rate. Stomatal conductance was generally higher in lodgepole than jack pine but it decreased sooner due to water stress in lodgepole pine and reached $1 / 3$ of the jack pine stomatal conductance by the end of the experiment (Fig. 3b).

Chemical Profiles The main differences in the chemical profile emitted by seedlings of the two pine species are that lodgepole pine (LP) emits a higher percentage of $\beta$ phellandrene $(27 \% \pm 2.25 \mathrm{SE})$ than jack pine $(1 \% \pm 0.26 \mathrm{SE})$ and jack pine (JP) releases more $\alpha$-pinene $(27 \% \pm 3.25 \mathrm{SE})$ than lodgepole pine ( $7 \% \pm 0.80 \mathrm{SE})$ (Fig. 4). 3-Carene makes up more of the volatile chemical profile in jack pine than lodgepole pine $(21 \% \pm 3.99 \mathrm{SE}$ in JP, $7 \% \pm 1.76 \mathrm{SE}$ in LP).

Volatile Emission The first axis of the lodgepole pine redundancy analysis $(\mathrm{RDA})(P<0.001)$ and of the jack pine RDA $(P=0.006)$ was significant. RDA triplots (Fig. 5) illustrate the relationship between the gas exchange parameters and volatile emission of the seedlings and water stress and biological treatments for each tree species.

In both species, 3 -carene emission correlated with fungal inoculation. Emission of the major compounds, $\beta$-phellandrene in lodgepole and $\alpha$-pinene in jack pine correlated with the physiological state (photosynthesis and stomatal conductance)

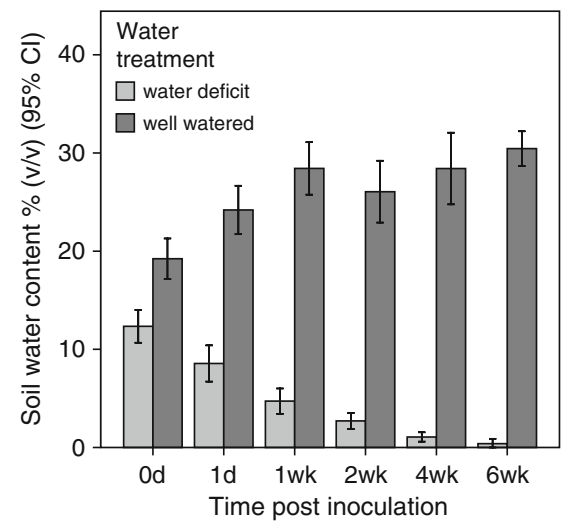

Fig. 2 Soil water content over time measured for pots containing lodgepole and jack pine seedlings. For each time point, data for the two species were combined. Error bars represent the 95\% confidence interval. Bars with non overlapping error bars are significantly different from each other of the seedling. The physiological parameters of stomatal conductance and photosynthesis correlated positively with soil water content in lodgepole but not jack pine seedlings.

In both lodgepole pine and jack pine, water deficit seedlings released significantly lesser amounts of total monoterpenes starting at week 4 of the experiment (Mann-Whitney $U$, lodgepole pine: $U=21, z=-2.94, P=$ 0.003; jack pine: $U=26, z=-2.66, P=0.008)$ and thus, all further analyses were conducted on water deficit and well watered seedlings separately. Biological treatments had a significant effect on total monoterpene emission in water deficit lodgepole pine seedlings [repeated measures ANOVA, $F(2,8)=6.329, P=0.022$; Fig. 6]. Subsequent pairwise comparison with Bonferroni correction of the timepoints revealed that 1 day after biological treatment application greater amounts of VOCs were emitted from lodgepole pine than at any other timepoint $(P=0.006$; Fig. 6). Further, pairwise comparison of the biological treatments showed that lodgepole pine seedlings that were inoculated with $G$. clavigera emitted significantly greater amounts of monoterpenes than controls $(P=0.029)$. Mechanically wounded seedlings also emitted greater amounts of volatiles than control seedlings but not at a significant level $(P=0.066)$. Well watered lodgepole pine demonstrated the same trends but showed no significant differences. In jack pine, the biological treatments had no significant influence on VOC emission. Lodgepole pine seedlings emitted lesser amounts than jack pine but the difference was not significant.

Tissue Extracts The number of detectable monoterpenes in the tissue extracts of both species was higher than in the volatile profiles (Table 1). Sabinene hydrate, cis-ocimene, $\alpha$-thujone, and pulgeone occurred only in lodgepole pine and were never detected in jack pine.

The overall needle monoterpene content in lodgepole pine seedlings is lower compared to previous year and current year growth bark [repeated measures ANOVA, $F(1.80,127.70)=118.37, P<0.001$; Fig. 7]. cis-Ocimene is the only terpenoid that did not follow this pattern and it occurred in higher concentration in the needles. All further analyses were conducted on the different tissues separately. The environmental treatment affected terpinolene, which occurred in higher concentrations in the current year and previous year bark of watered seedlings [ANOVA, $F(1,70)=$ 3.999, $P=0.028$ and $F(1,70)=5.059, P=0.049$, respectively] than in the water deficit seedlings. Less bornyl acetate occurred in the previous year's bark of watered seedlings [ANOVA, $F(1,70)=5.265, P=0.025]$ compared to seedlings subjected to water deficit. The biological treatments had no effect on any of the measured terpenoids in the tissue extracts.

Like lodgepole pine, jack pine needles had a significantly lower overall monoterpene content than current year or previous year bark [repeated measures ANOVA, $F(2,142)=$ 
Fig. 3 Changes in gas exchange parameters over time shown for both water treatments in lodgepole and jack pine seedlings (a) rate of photosynthesis (b) stomatal conductance. Error bars represent the $95 \%$ confidence interval. Bars with non overlapping error bars are significantly different from each other

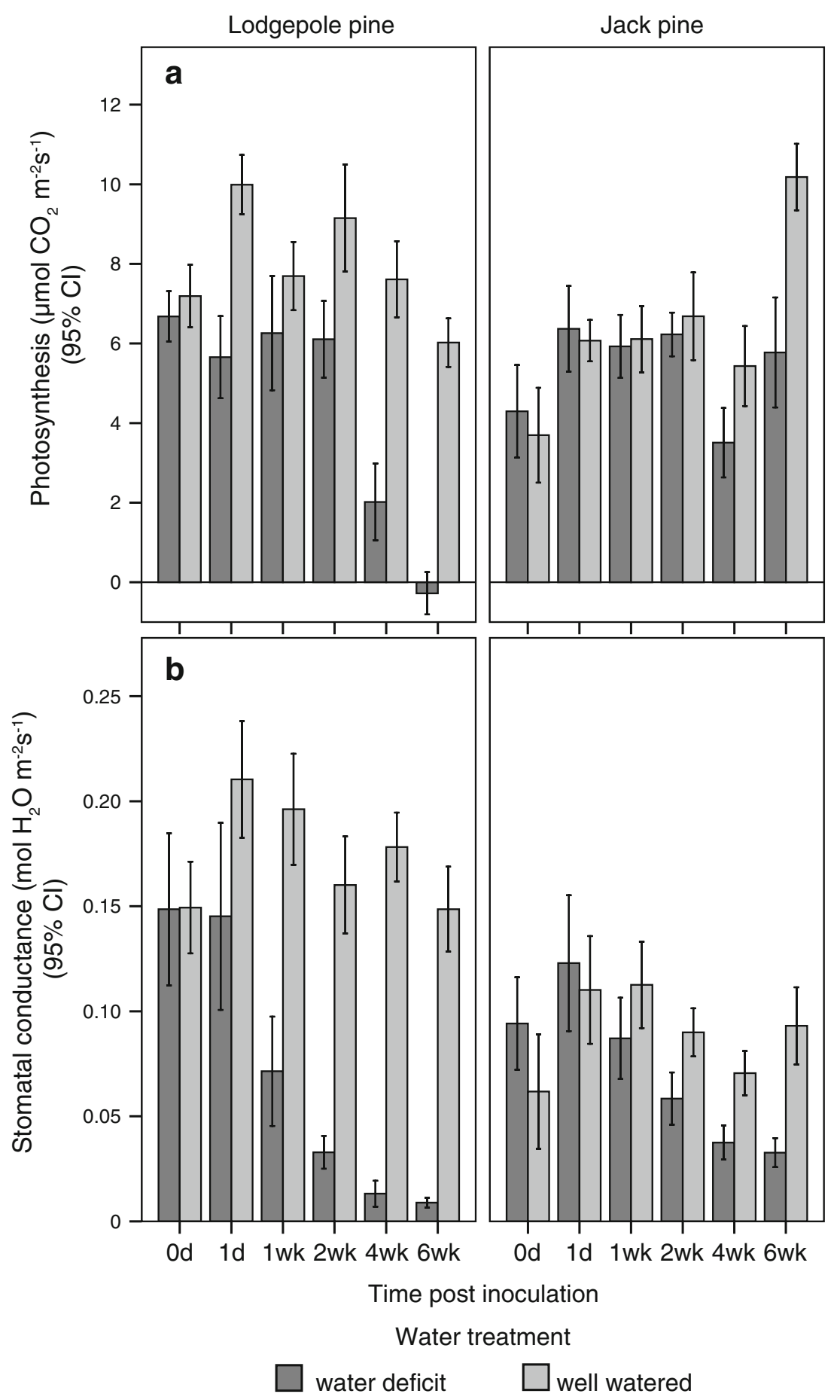

115.66, $P<0.001$; Fig. 7]. The environmental treatment had no effect on monoterepene content of jack pine tissues. The bornyl acetate content in the previous year bark of fungal-inoculated seedlings was higher than in wounded seedlings [Kruskal-Wallis, $H(2)=16.467, P<$ 0.001; Fig. 8].

The overall monoterpene content of all tissues increased in both species over time independent from any manipulation (Fig. 9). Both species exhibit similar terpenoid content in collected bark tissues, but jack pine needles contain more terpenoids compared to those from lodgepole pine [t-test, $t$ $(117.664)=3.413, P=0.001$; Fig. 7].

\section{Discussion}

Water regime manipulation and stimulation of plant defenses affected the emission of VOCs differently in the two studied 

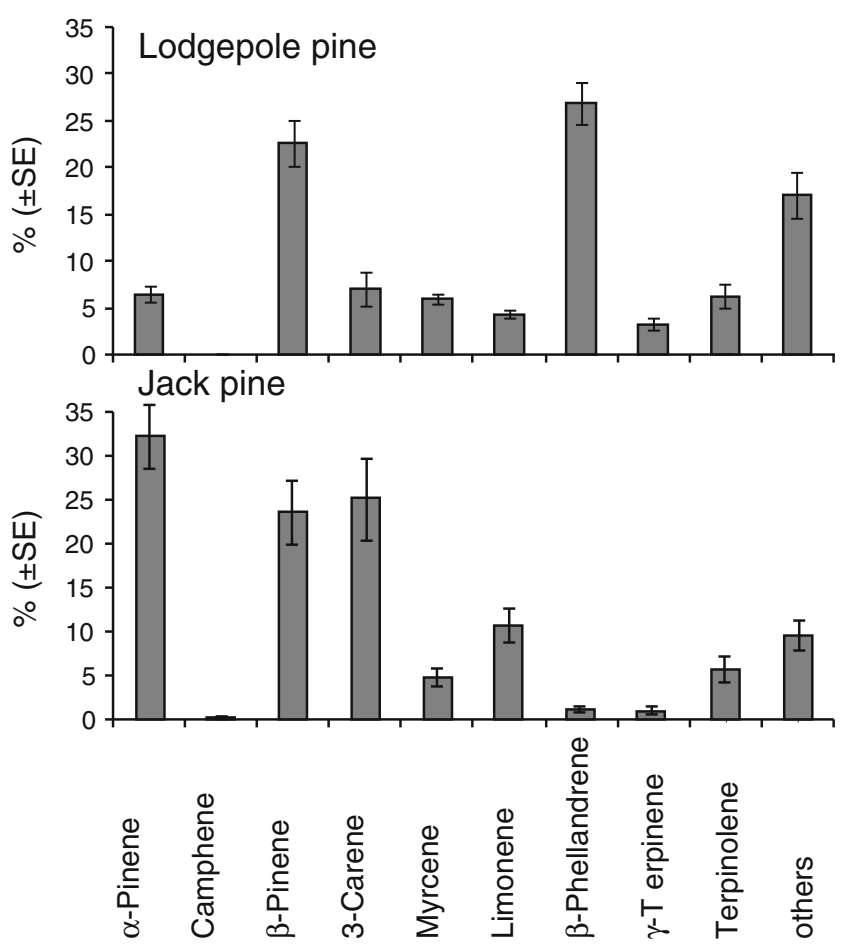

Fig. 4 Chemical profiles presented as percent of volatile organic compounds emitted from lodgepole pine and jack pine seedlings based on peak area in GC analysis. Error bars indicate standard errors

pine species. In general, jack pine emitted higher amounts of 3 -carene $(21 \%)$, compared to lodgepole pine $(7 \%)$ while lodgepole pine released higher amounts of $\beta$-phellandrene $(27 \%)$ than jack pine (1\%) (Fig. 4). $\beta$-Phellandrene is the only monoterpene that attracts MPB in the absence of aggregation pheromones when released at high doses (Miller and Borden, 1990), which could mean that pure jack pine stands might fail to attract pioneer beetles flying actively into the region compared to lodgepole pine stands.

The chemical profile of jack pine seedlings tested in our study contained $21 \%$ of 3 -carene on average, similar to previous reports of jack pine from central Saskatchewan, Canada (Pauly and von Rudolff, 1971) and consistent with the profile of mature jack pine in the Smoky Lake region of Alberta (unpublished data). Within the wide range of jack pine in North America, there are surprisingly few records available on chemical profiles of jack pine, and almost all records are from the most southern extension of the jack pine forest in Wisconsin, USA. In those studies, the chemical profiles consist primarily of $\alpha$ - and $\beta$-pinene; 3 -carene was either not found or occurred only in trace amounts (Zavarin et al., 1969; Wallin and Raffa, 1999; Erbilgin et al., 2001; Aukema et al., 2010). An early study that directly compared resin monoterpene composition among lodgepole pine, jack pine, and their hybrids found 3-carene to be a signature compound in lodgepole pine that could distinguish it from jack pine (Zavarin et al., 1969). This large variability of 3- carene in jack pine monoterpene profiles suggests either that there are two or more phytochemical phenotypes in jack pine, similar to lodgepole pine (Forrest, 1980), or that there is a greater degree of introgression of lodgepole pine genes into jack pine in the western extent of the jack pine range than originally assumed. A similar variability of 3-carene content occurs in Scots pine seedlings from different provenances in Turkey and Finland (Semiz et al., 2007), suggesting that terpenoid synthesis is under genetic control and differs by geographical origin of the seeds. Clarification of the role, if any, of 3-carene in jack pine profiles is essential in order to predict the potential interaction between MPB and jack pine in the boreal forest.

The chemical profile measured from lodgepole pine seedlings in our study is in agreement with existing published profiles (Zavarin et al., 1969; Pauly and von Rudolff, 1971; Pureswaran et al., 2004a). The consistency in monoterpene profiles of lodgepole pine resin has enabled the use of chemosystematics across the geographic range of the species (Forrest, 1980). Chemical profiles are used to distinguish subspecies/varieties of lodgepole pine, which are: subsp. contorta, bolanderi, murrayana, and latifolia (Critchfield, 1957). Chemotyping only failed to distinguish the lodgepole pine subspecies murrayana and latifolia (Forrest, 1980; Bohm, 2009). Our results underscore the need for a thorough study to chemotype jack pine trees across its broad range.

Seedlings of both species emitted an overall lower quantity of VOCs under water deficit conditions, which was evident at day one of the experiment but significant at week four (Fig. 6). Although emission of VOCs is not thought to be controlled by stomatal conductance (Sharkey, 1991; Kesselmeier and Staudt, 1999; Blanch et al., 2007), in our study stomatal conductance may have indicated the general condition of seedlings and thus indirectly affected the efficiency of monoterpene synthesis in the plant to increase monoterpene emission rates. Similarly, VOC emission was strongly reduced by severe drought conditions and linked to stomatal closure in common Mediterranean woody species including Pinus halepensis (Llusià and Peñuelas, 1998). Although in a similar study, Pinus halepensis seedlings exposed to moderate drought conditions exhibited no change in VOC emission as a result of water deficit (Blanch et al., 2007). In our study, stomatal conductance explained the release of some of the most abundant monoterpenes in lodgepole pine and jack pine. Likewise, Niinemets et al. (2002) concluded that stomatal conductance in Pinus pinea affected the emission of alcohols, aldehydes, carboxylic acids, and oxygenated monoterpenoids. This finding should be considered in monoterpenoid emission models that currently use a simple equation that relies mainly on temperature to describe the monoterpene efflux from foliage (Guenther et al., 1991) and does not consider any role of 
Fig. 5 Canonical redundancy analysis (RDA) triplots (scaling 2) illustrating the effect of environmental and biological treatments as well as seedling physiology on volatile emission of individual and total monoterpenes in lodgepole and jack pine
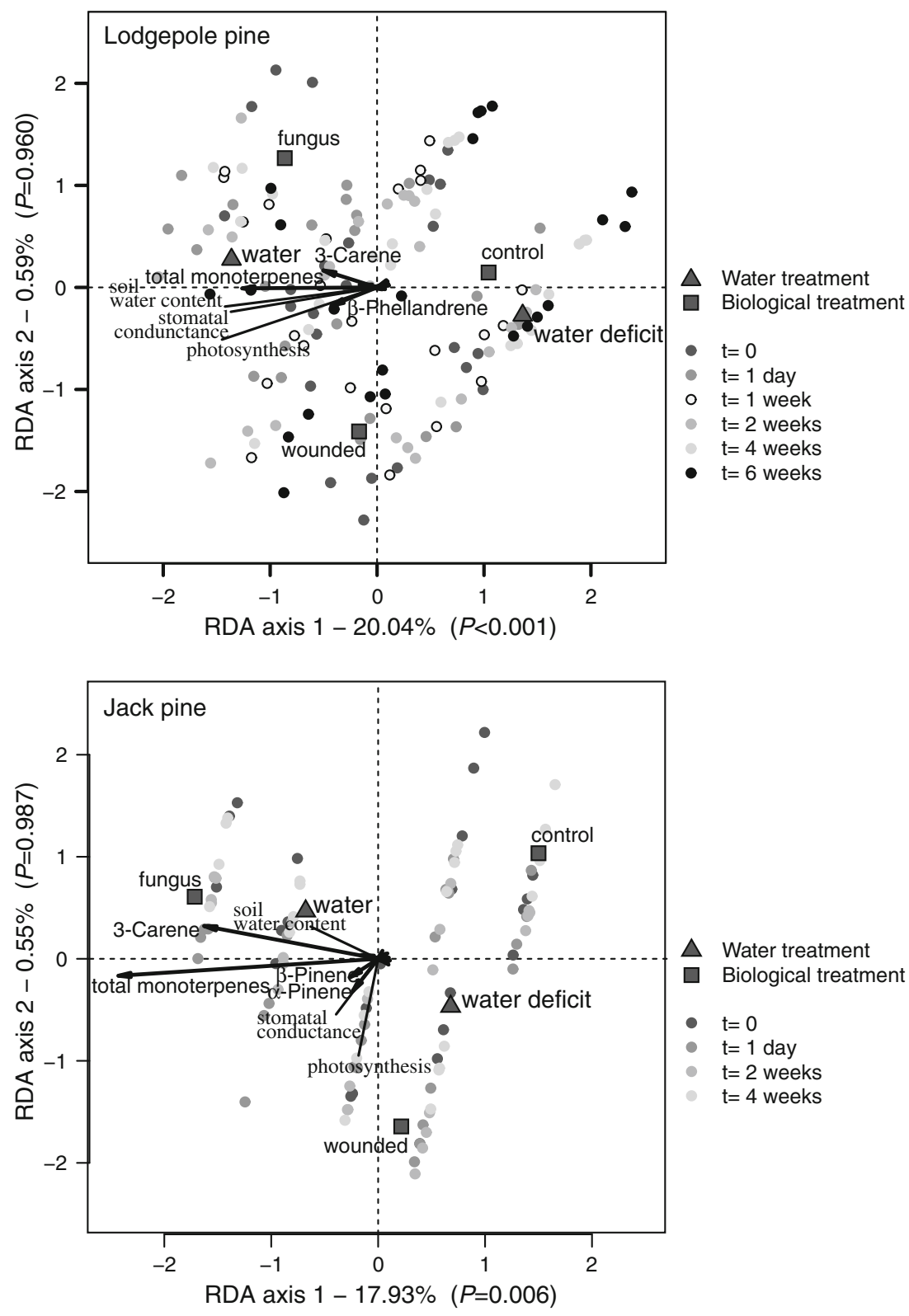

stomatal conductance in VOCs emission (Sharkey, 1991; Kesselmeier and Staudt, 1999).

Stomatal conductance and the resulting gas exchange that is essential for the carbon reactions of photosynthesis depend on the water transport from soil to leaf. Plant species categorized as isohydric exhibit tight control over stomatal aperture in response to soil water deficit as a means to regulate water loss; whereas species classified as anisohydric do not (Tardieu and Simonneau, 1998; McDowell et al., 2008). Stomatal conductance in lodgepole pine seedlings in the current study was higher than that in jack pine and responded more quickly to a decrease in soil water content (Fig. 3). Jack pine appears to be better adapted to low water availability than lodgepole pine, which is consistent with the success of jack pine in dry and nutrient poor soils across its natural range (Vidacović, 1991). In our study, soil moisture content influenced the physiological state of pine species differently. The RDA results (Fig. 5) support the findings that jack pine is better adapted to water deficit conditions, as the physiological state of lodgepole pine but not that of jack pine was correlated with soil water content.

Fungal inoculation of seedlings with an MPB associated fungus also altered the VOC emissions in both pine species. 3-Carene emission increased and was correlated with fungal inoculation in both lodgepole and jack pine (Fig. 5). Mature jack pine trees inoculated with the pine engraver, Ips pini, associated fungus Ophiostoma ips had increased 3-carene phloem content (Raffa and Smalley, 1995). Jost et al. (2008) inoculated mature lodgepole and jack pine trees as well as their hybrids with MPB associated fungi and collected bark 


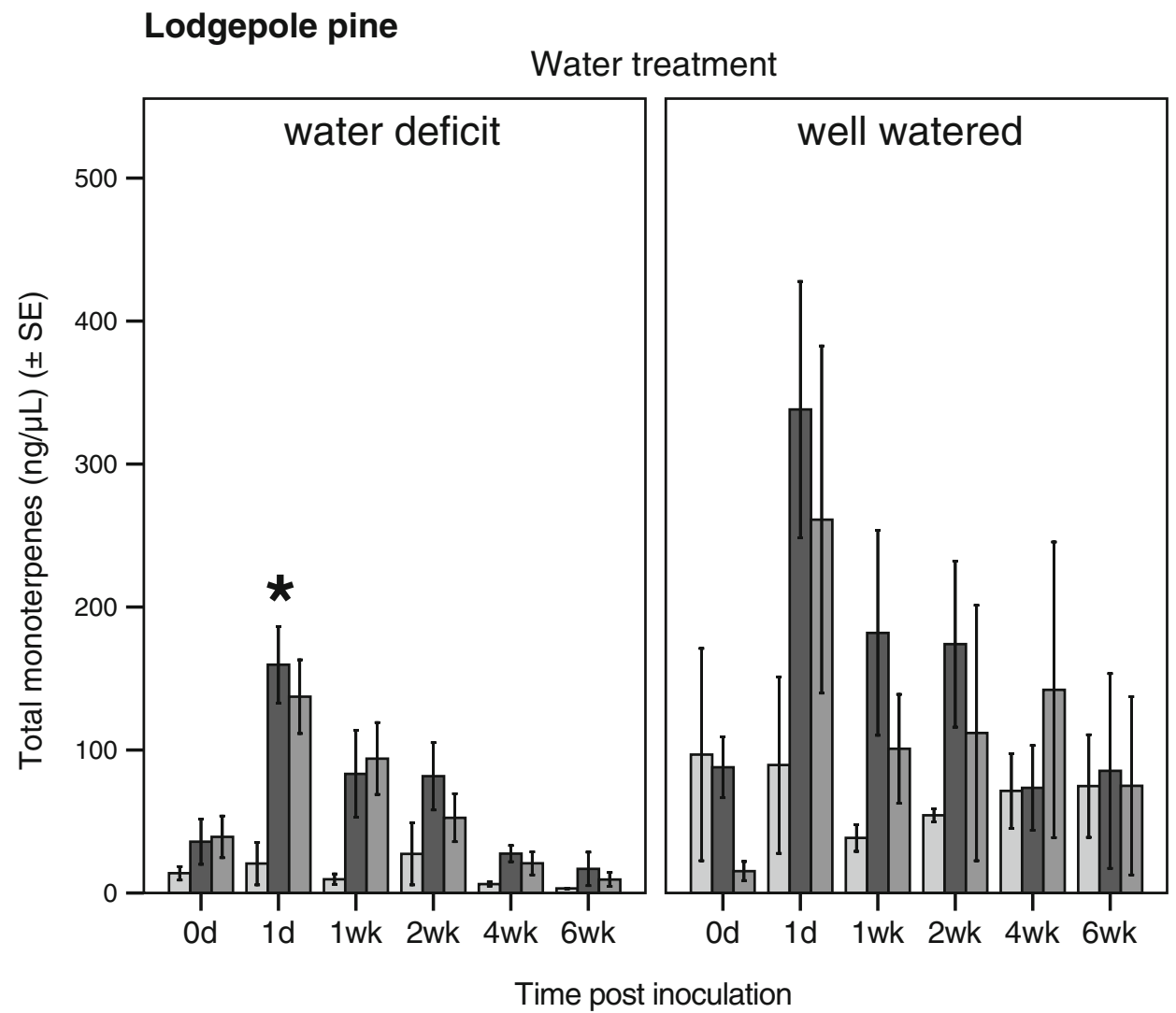

Biological

treatment

$\square$ control

$\square$ fungus

$\square$ wounded

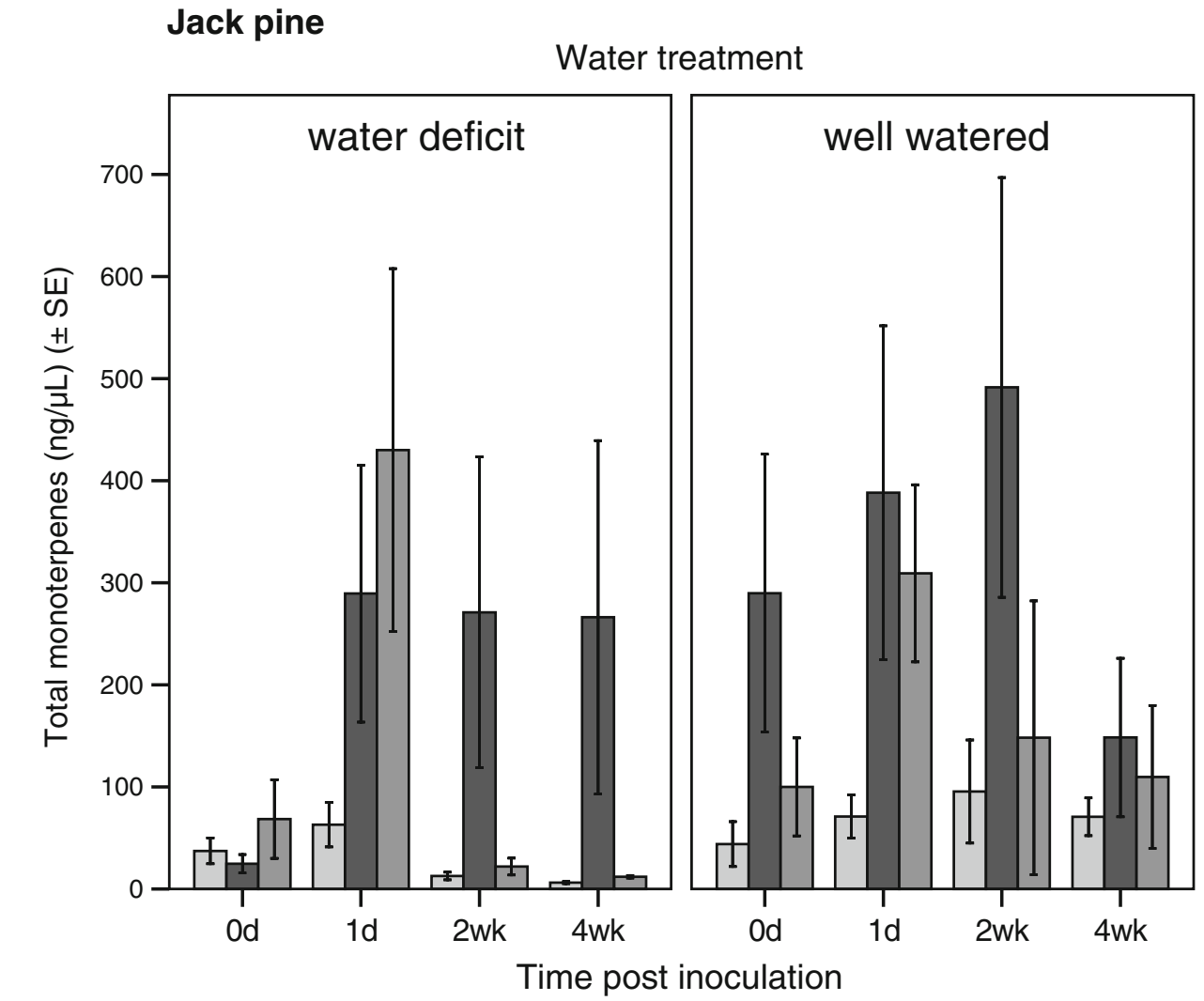

Biological

treatment

$\square$ control

$\square$ fungus

$\square$ wounded

Fig. 6 Effect of water and biological treatment on total monoterpene difference of total monoterpene emission in fungal inoculated water emission by lodgepole and jack pine seedlings over time. Error bars deficit lodgepole pines compared to the control treatment $(P=0.029)$ indicate standard errors. The asterisk indicates the significant 
Table 1 Monoterpene content of the different tissues in lodgepole and jack pine (\% of amount ng/mg tissue)

\begin{tabular}{|c|c|c|c|c|c|c|c|c|c|c|c|c|}
\hline \multirow{3}{*}{$\begin{array}{l}\text { Monoterpene } \\
\alpha \text {-Pinene }\end{array}$} & \multicolumn{6}{|c|}{ Lodgepole pine } & \multicolumn{6}{|c|}{ Jack pine } \\
\hline & \multicolumn{2}{|c|}{$\begin{array}{l}\text { Needles } \\
\text { mean }( \pm \text { SE })\end{array}$} & \multicolumn{2}{|c|}{$\begin{array}{l}\text { Current year } \\
\text { bark mean }( \pm \mathrm{SE})\end{array}$} & \multicolumn{2}{|c|}{$\begin{array}{l}\text { Previous year } \\
\text { bark mean }( \pm \mathrm{SE})\end{array}$} & \multicolumn{2}{|c|}{$\begin{array}{l}\text { Needles } \\
\text { mean }( \pm \text { SE })\end{array}$} & \multicolumn{2}{|c|}{$\begin{array}{l}\text { Current year } \\
\text { bark mean }( \pm \mathrm{SE})\end{array}$} & \multicolumn{2}{|c|}{$\begin{array}{l}\text { Previous year } \\
\text { bark mean }( \pm \mathrm{SE})\end{array}$} \\
\hline & 6.55 & 0.78 & 5.57 & 0.69 & 6.65 & 0.81 & 24.03 & 4.96 & 24.55 & 6.24 & 29.75 & 6.27 \\
\hline Camphene & 3.19 & 1.42 & 2.47 & 0.95 & 3.87 & 1.26 & 0.91 & 0.44 & 0.97 & 0.31 & 1.95 & 0.33 \\
\hline$\beta$-Pinene & 20.78 & 3.01 & 25.19 & 3.41 & 27.23 & 3.55 & 6.92 & 1.81 & 8.08 & 1.53 & 14.64 & 3.04 \\
\hline 3-Carene & 15.64 & 2.64 & 12.97 & 3.16 & 15.39 & 3.17 & 38.66 & 8.00 & 47.12 & 8.78 & 42.6 & 8.89 \\
\hline Myrcene & 7.31 & 0.32 & 5.69 & 0.18 & 5.35 & 0.25 & 4.87 & 0.26 & 3.29 & 0.09 & 3.09 & 0.07 \\
\hline Limonene & 3.94 & 0.22 & 8.14 & 1.72 & 6.43 & 0.85 & 19.12 & 5.52 & 12.77 & 4.04 & 4.84 & 1.28 \\
\hline$\beta$-Phellandrene & 31.99 & 3.77 & 34.30 & 2.83 & 27.25 & 3.99 & 2.63 & 1.19 & 1.05 & 0.22 & 1.04 & 0.13 \\
\hline cis-Ocimene & 1.68 & 0.15 & 0.46 & 0.17 & 0.34 & 0.10 & 0 & 0 & 0 & 0 & 0 & 0 \\
\hline$\gamma$-Terpinene & 0.50 & 0.05 & 0.15 & 0.02 & 0.17 & 0.01 & 0.34 & 0.11 & 0.27 & 0.05 & 0.22 & 0.04 \\
\hline Terpinolene & 0.13 & 0.07 & 0.36 & 0.07 & 0.37 & 0.06 & 0.66 & 0.15 & 1.03 & 0.22 & 0.82 & 0.2 \\
\hline$\alpha$-Thujone & 0.37 & 0.04 & 0.13 & 0.01 & 0.13 & 0.01 & 0 & 0 & 0 & 0 & 0 & 0 \\
\hline$\beta$-Thujone & 0.61 & 0.06 & 0.22 & 0.02 & 0.22 & 0.02 & 0.22 & 0.12 & 0.09 & 0.06 & 0.07 & 0.04 \\
\hline Sabinene hydrate & 0 & 0 & 0.01 & 0.01 & 0.02 & 0.01 & 0 & 0 & 0 & 0 & 0 & 0 \\
\hline Camphor & 1.37 & 0.14 & 0.49 & 0.05 & 0.55 & 0.07 & 0.40 & 0.22 & 0.16 & 0.11 & 0.13 & 0.07 \\
\hline Linalool & 0.34 & 0.13 & 0.15 & 0.03 & 0.17 & 0.05 & 0.07 & 0.07 & 0.05 & 0.03 & 0.03 & 0.03 \\
\hline Bornyl acetate & 3.73 & 1.71 & 2.83 & 1.42 & 5.1 & 2.01 & 0.89 & 0.23 & 0.33 & 0.10 & 0.45 & 0.10 \\
\hline Pulgeone & 0.76 & 0.08 & 0.29 & 0.03 & 0.29 & 0.02 & 0 & 0 & 0 & 0 & 0 & 0 \\
\hline$\alpha$-Humulene & 0.21 & 0.09 & 0.07 & 0.02 & 0.12 & 0.04 & 0.05 & 0.05 & 0 & 0 & 0 & 0 \\
\hline$\alpha$-Terpineol & 0.01 & 0.01 & 0.08 & 0.03 & 0.04 & 0.02 & 0.22 & 0.09 & 0.24 & 0.07 & 0.36 & 0.08 \\
\hline Borneol & 0.88 & 0.20 & 0.42 & 0.20 & 0.31 & 0.09 & 0 & 0 & 0 & 0 & 0.02 & 0.02 \\
\hline
\end{tabular}

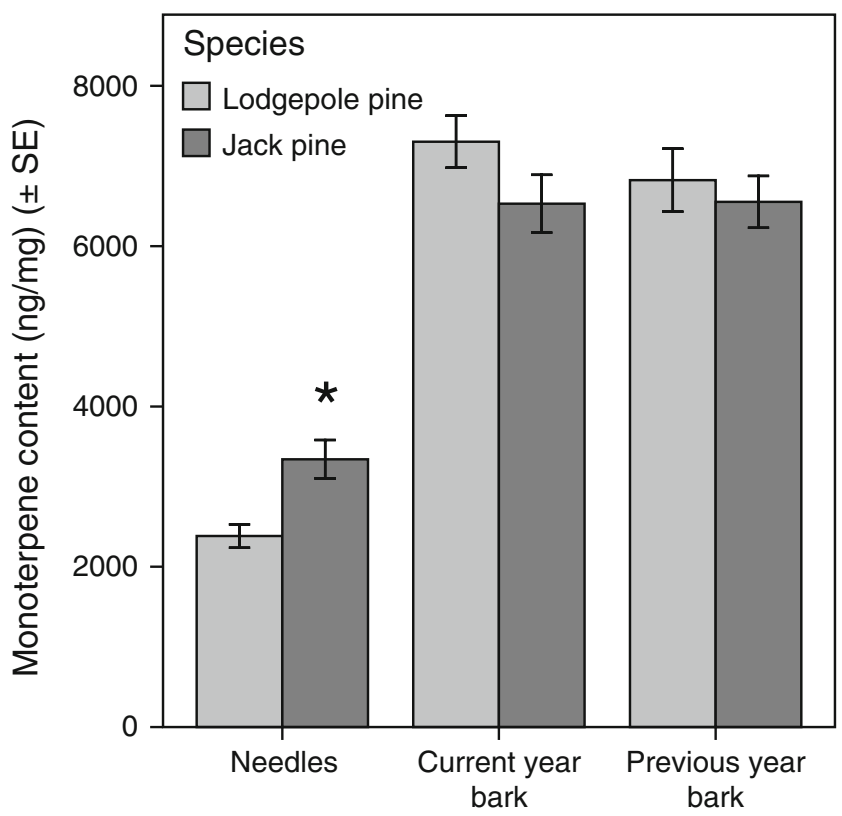

Fig. 7 Total monoterpene content in the three different tissues of lodgepole and jack pine seedlings. Error bars indicate standard error. The asterisk indicates the significant difference in monoterpene content between lodgepole and jack pine needles

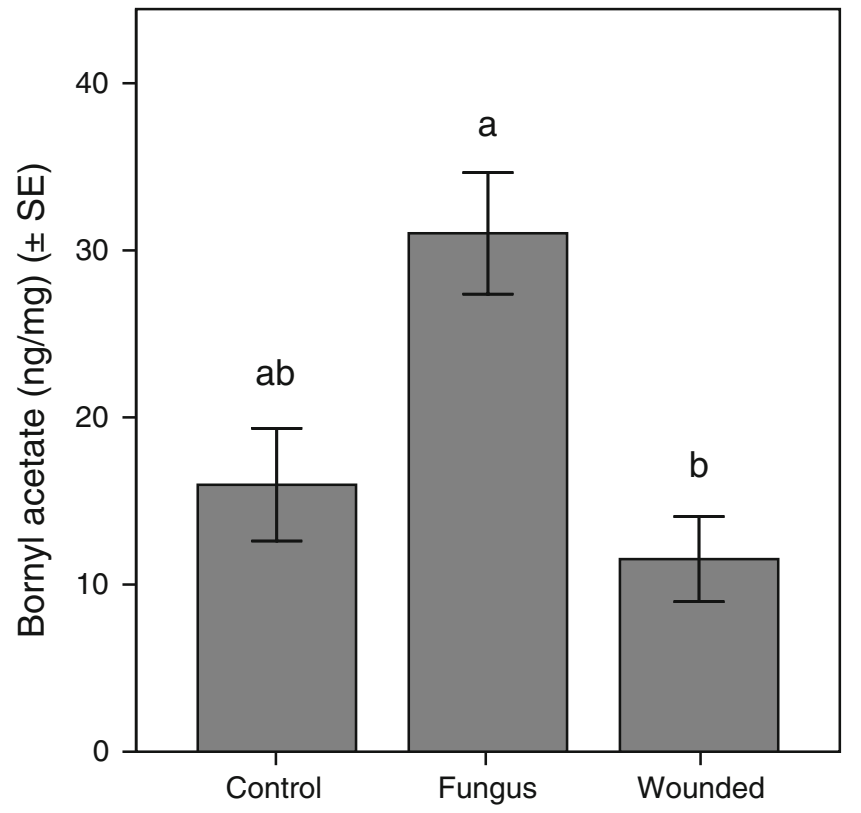

Fig. 8 Different bornyl acetate concentrations in previous year's bark of jack pine caused by the biological treatments. Kruskal-Wallis test was used followed up by Mann-Whitney $U$ tests. A Bonferroni correction was applied and so all effects are reported at a 0.025 level of significance. Different lowercase letters indicate a statistically significant difference 


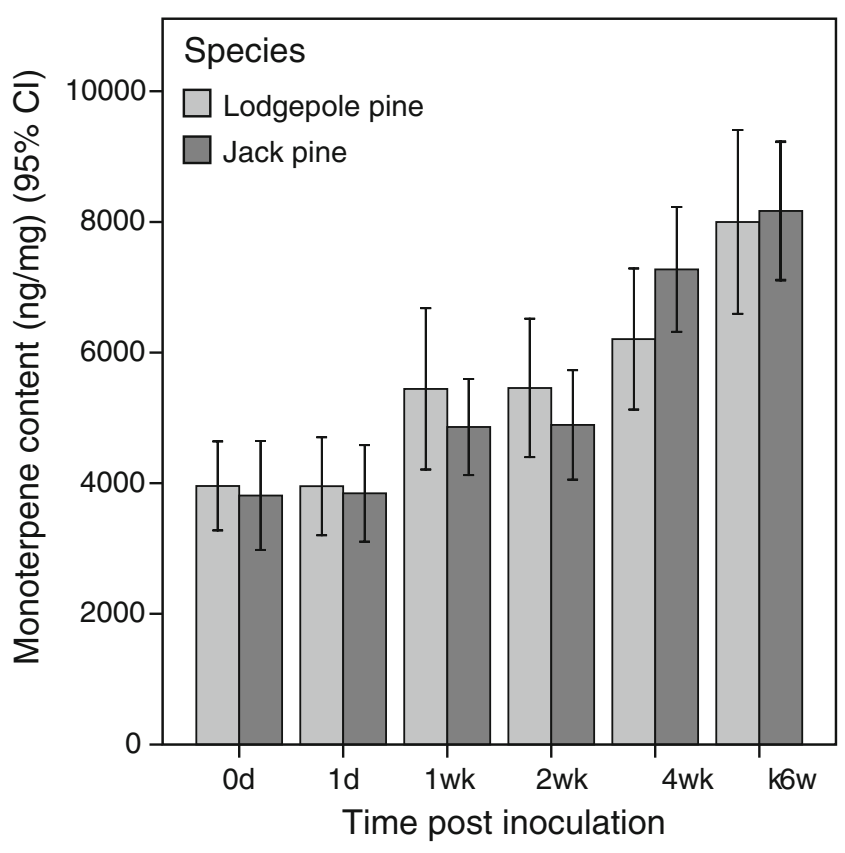

Fig. 9 Total monoterpene increase over time in all tissues of lodgepole and jack pine seedlings across all treatments. Error bars represent the $95 \%$ confidence interval. Bars with non overlapping error bars are significantly different from each other

volatiles after a 6-week inoculation period. Unfortunately, they did not measure 3 -carene, and the only significant difference they found was a strong reduction in $\alpha$-pinene emission in fungal inoculated lodgepole pine. Direct comparison of the two studies is difficult since they did not quantify their results but only compared ratios. During our experiment, the fungal inoculated lodgepole pine seedlings always released more $\alpha$-pinene than the controls. Resin monoterpenes from ponderosa pine including $\alpha$ - and $\beta$-pinene, 3-carene, limonene, and terpinolene have antifungal properties (Himejima et al., 1992). Monoterpenes and other chemical compounds in the resin of host pine inhibit the growth of bark beetle-associated fungi in the southern US coniferous system (Bridges, 1987; Klepzig et al., 1996). There is growing evidence that plants respond to microbial attack by releasing volatiles, which initiates defense mechanisms by signaling within as well as possibly between plants (Kesselmeier and Staudt, 1999). Volatile organic compounds released from inoculated plants induce the resistance to fungi in Arabidopsis (Kishimoto et al., 2006), but little is known about plant communication in conifers (Heil and Karban, 2009). The increased emission of 3-carene after fungal inoculation in our study might be due to allocation of that compound towards the inoculation site by the plant, thus fighting the fungus and the wound facilitating its release. In particular, damaged bark can be a major source for VOC emission in conifer seedlings (Heijari et al., 2011).
In the current study, we sampled both volatile and tissue chemistry of both pine species in response to water stress and biological treatments. There are fewer detectable monoterpenes in the seedling volatile profiles compared to monoterpene content in bark and needles. Monoterpene concentration in bark (phloem) and needles also can respond to drought stress (Hodges and Lorio, 1975; Llusià and Peñuelas, 1998). Monoterpenes and resin acids in the woody tissue of Scots pine and Norway spruce seedlings significantly increased as a result of drought exposure (Turtola et al., 2003). In our study, water deficit had no effect on overall monoterpene content in either tissue type. In fact, terpinolene concentration decreased in the bark as a result of water deficit in the lodgepole pine seedlings. The only compound that significantly increased due to water deficit was bornyl acetate in the previous year's bark of lodgepole pine seedlings. The levels of bornyl acetate also was associated with fungal inoculation in jack pine previous year's bark (Fig. 8). Increased bornyl acetate concentrations in the resin of lodgepole pine are associated with Armillaria root disease (Armillaria mellea) (Nebeker et al., 1995). Bornyl acetate levels also increase in root and stem tissue of Douglas-fir seedlings (Pseudotsuga menziesii) treated with methyl jasmonate, a phytohormone implicated in mediating defense responses (Huber et al., 2005). In some areas, MPB attack is linked to pines infested with A. mellea (Tkacz and Schmitz, 1986). Mountain pine beetle antennae do not respond to bornyl acetate (Pureswaran et al., 2004b), but it is possible that it can taste this compound since olfactory and gustatory information are processed in different areas of the insect brain (DeBruyne and Warr, 2006). Gustatory assessment could be way for MPB to evaluate the health status of a host tree and to determine how well defended it is.

The primary goal of our study was to evaluate the chemical profiles of jack pine and lodgepole pine trees and to make reasonable assumptions about jack pine suitability as a potential host to MPB based on its chemistry. All volatile monoterpenes emitted by lodgepole and jack pine seedlings in the study can be detected by the MPB (Huber et al., 2000; Pureswaran et al., 2004b). Some of these host monoterpenes synergize MPB response to the aggregation pheromones trans-verbenol and exo-brevicomin in trapping studies (Borden et al., 2008). There is strong evidence that myrcene, 3-carene, terpinolene, and $\alpha$-pinene synergize MPB aggregation pheromone response (Borden et al., 2008). In olfactometer tests, 3-carene was most attractive to MPB out of 20 tested compounds (Conn, 1981). In our study, 3-carene emission increased with plant defense stimulation by G. clavigera. This compound might function as an indicator of a weakened tree and could support the aggregation of beetles on susceptible hosts. MPB is able to distinguish between host and non-host volatiles, and may 
also use host volatiles to identify weak hosts and avoid the risks associated with trying to overcome tree defenses of a healthy host (Keeling and Bohlmann, 2006). Jack pine emits about three times more 3-carene than lodgepole pine, suggesting that it may be more prone to MPB attacks (Conn, 1981; Borden et al., 2008). Further, jack pine bark contains higher concentrations of $\alpha$-pinene than lodgepole pine, and $\alpha$-pinene can be a synergist for the MPB aggregation pheromone, and it is also a precursor for production of transverbenol, the primary component of MPB aggregation pheromone (Borden et al., 2008).

This study enabled us to compare VOC emission and monoterpene content between lodgepole and jack pine exposed to water stress and different biological treatments under controlled and easy to manipulate conditions. The results suggest that monoterpenes that play a role in pineMPB interactions differ between lodgepole and jack pine, and also that they are affected by water availability. Shrimpton and Watson (1971) recommended the use of lodgepole pine seedling for studying wound response, since seedlings and mature trees are identical in their resistant response. Nevertheless, inferences made from our study to MPB host use are limited as beetles do not attack trees at the seedling stage. The results from this study, however, are useful for developing the models that guide rational design of field studies, with their inherently greater degree of difficulty and experimental variance. Additional field experiments to understand chemically-mediated interactions among MPB, its associated fungus, and its pine hosts under water deficit conditions are currently being conducted in mature lodgepole, jack and hybrid pine stands. Future studies will assess the behavioral importance of the host monoterpenes from the two species in host detection and acceptance by MPB.

\begin{abstract}
Acknowledgements We thank two anonymous reviewers for helpful suggestions on an earlier version of this manuscript. We acknowledge the lab members of Janice E. K. Cooke as well as Boyd Mori for help potting the seedlings; Miles Dyck for providing us with the TDR equipment; Celia Boone for sharing $\beta$-phellandrene; Patrick James for an introduction to R; and Joanne Mann (West Fraser Mills Ltd., Hinton Wood Products), Michael Bendzsak (Saskatchewan Forest Centre), and Glenn Goodwill, Candace Kent and Stewart HaywoodFarmer (PRT) for providing seedlings. We particularly acknowledge Adrianne Rice for providing fungal culture and knowledge, and Jeremiah Bolstad and Andrew Ho for the help during the sample extraction process.

Funding for this research has been provided through grants from the Government of Alberta through Genome Alberta, the Government of British Columbia through Genome BC and Genome Canada in support of the Tria 1 and Tria 2 projects (http://www.thetriaproject.ca) of which MLE, JEKC, and NE are co-investigators.
\end{abstract}

\section{References}

Aukema, B. H., Powell, J. S., Clayton, M. K., and RafFa, K. F. 2010. Variation in complex semiochemical signals arising from insects and host plants. Environ. Entomol. 39:874-882.
Blanch, J.-S., Peñuelas J., and Llusià, J. 2007. Sensitivity of terpene emissions to drought and fertilization in terpene-storing Pinus halepensis and non-storing Quercus ilex. Physiol. Plantarum 131:221-225.

Blompuist, G. J., Figueroa-Teran, R., Aw, M., Song, M., Gorzalski, A., AbBott, N. L., Chang, E., and TitTiger, C. 2010. Pheromone production in bark beetles. Insect Biochem. Mol. 40:699-712.

BoHm, B. A. 2009. The Geography of Phytochemical Races. Springer, New York.

Borden, J. H., Pureswaran, D. S., and Lafontaine, J. P. 2008. Synergistic blends of monoterpenes for aggregation pheromones of the mountain pine beetle (Coleoptera: Curculionidae). J. Econ. Entomol. 101:1266-1275.

Breshears, D. D., Myers, O. B., Meyer, C. W., Barnes, F. J., Zou, C. B., Allen, C. D., McDowell, N. G., and Pockman, W. T. 2009. Tree die-off in response to global change-type drought: Mortality insights from a decade of plant water potential measurements. Front. Ecol. Environ. 7:185-189.

BRIDGES, J. R. 1987. Effects of terpenoid compounds on growth of symbiotic fungi associated with the southern pine beetle. Phytopathology 77: 83-85.

Carroll, A. L., Régnière, J., Logan, J. A., Taylor, S. W., Bentz, B. J., and Powell, J. A. 2006. Impacts of climate change on range expansion by the mountain pine beetle. Natural Resources Canada, Canadian Forest Service, Pacific Forestry Centre, Victoria, BC. Mountain Pine Beetle Initiative Working Paper 2006-14. p. 20.

Cerezke, H. F. 1995. Egg gallery, brood production, and adult characteristics of mountain pine beetle, Dendroctonus ponderosae Hopkins (Coleoptera: Scolytidae), in three pine hosts. Can. Entomol. 127:955-965.

ConN, J. E. 1981. Pheromone Production and Control Mechanisms in Dendroctonus ponderosae Hopkins. M.Sc. thesis, Simon Fraser University, Burnaby, B.C.

Critchifield, W. B. 1957. Geographic Variation in Pinus contorta. Harvard University, Cambridge, Massachusetts. Maria Moors Cabot Found. Publ. 3.

Cullingham, C. I., CoOKe, J. E. K., Dang, S., Davis, C. S., Cooke, B. J., and Coltman, D. W. 2011. Mountain pine beetle host-range expansion threatens the boreal forest. Mol. Ecol. 20:2157-2171.

DeBrUyNe, M. and WARR, C. G. 2006. Molecular and cellular organization of insect chemosensory neurons. BioEssays 28:23-34.

Erbilgin, N., Szele, A., KlePZig, K. D., and RAFFA, K. F. 2001. Trap type, chirality of $\alpha$-pinene, and geographic region affect sampling efficiency of root and lower stem insects in pine. $J$. Econ. Entomol. 94:1113-1121.

Faccoli, M., BlaŽEneC, M., and Schlyter, F. 2005. Feeding response to host and nonhost compounds by males and females of the spruce bark beetle Ips typographus in a tunneling microassay. J. Chem. Ecol. 31:745-759.

FORREST, G. I. 1980. Geographical variation in the monoterpenes of Pinus contorta oleoresin. Biochem. Syst. Ecol. 8:343-359.

Franceschi, V. R., KroKene, P., Christiansen, E., and KreKling, T. 2005. Anatomical and chemical defenses of conifer bark against bark beetles and other pests. New Phytol. 167:353-376.

GolLOB, L. 1980. Monoterpene composition in bark beetle-resistant loblolly pine. Naturwissenschaften 67:409-410.

Guenther, A. B., Monson, R. K., and Fall, R. 1991. Isoprene and monoterpene emission rate variability: Observation with Eucalyptus and emission rate algorithm development. J. Geophys. Res. 96:10799-10808.

Heijari, J., Blandea, J. D., and Holopainen, J. K. 2011. Feeding of large pine weevil on Scots pine stem triggers localised bark and systemic shoot emission of volatile organic compounds. Environ. Exp. Bot. 71:390-398. 
HeIL, M. and KARBAN, R. 2009. Explaining evolution of plant communication by airborne signals. Trends Ecol. Evol. 25:137144

HiLlel, D. 1998. Environmental Soil Physics. Academic Press, San Diego, California.

Himejima, M., Hobson, K. R., OtsuKa, T., Wood, D. L., and Kubo, I. 1992. Antimicrobial terpenes from oleoresin of ponderosa pine tree (Pinus ponderosa): A defense mechanism against microbial invasion. J. Chem. Ecol. 18:1809-1818.

Hodges, J. D. and LoRIO JR., P. L. 1975. Moisture stress and composition of xylem oleoresin in loblolly pine. For Sci. 21:283-290

Huber, D. P. W., Gries, R., Borden, J. H., and Pierce Jr., H. D. 2000. A survey of antennal responses by five species if coniferophagous bark beetles (Coleoptera: Scolytidae) to bark volatiles of six species of angiosperm trees. Chemoecology 10:103-113.

Huber, D. P. W., Philippe, R. N., Madilao, L. L., Sturrock, R. N., and BohlmanN, J. 2005. Changes in anatomy and terpene chemistry in roots of Douglas-fir seedlings following treatment with methyl jasmonate. Tree Physiol. 25:1075-1083.

Jost, R. W., Rice, A. V., Langor, D. W., and BoluK, Y. 2008. Monoterpene emission from lodgepole and jack pine bark inoculatied with mountain pine beetle-associated fungi. J. Wood Chem. Tech. 28:37-46.

KeEling, C. I. and Bohlmann, J. 2006. Genes, enzymes and chemicals of terpenoid diversity in the constitutive and induced defence on conifers against insects and pathogens. New Phytol. 170:657-675.

Kesselmeier, J. and StAudT, M. 1999. Biogenic volatile organic compounds (VOC): An overview on emission, physiology and ecology. J. Atmos. Chem. 33:23-88.

Kishimoto, K., Matsui, K., OzaWa, R., and Takabayashi, J. 2006. Analysis of defensive responses activated by volatile alloocimene treatment in Arabidopsis thaliana. Phytochemistry 67:1520-1529

Klepzig, K. D., Smalley, E. B., and Raffa, K. F. 1996. Combined chemical defenses against an insect-fungal complex. J. Chem. Ecol. 22:1367-1388.

LEGENDRE, P. and LEGENDRE, L. 1998. Numerical Ecology. Elsevier, Amsterdam.

LEGENDRE, P. and DuRAND, S. 2010. rdaTest: Canonical redundancy analysis (R package version 1.7). URL http://www.bio.umontreal. ca/legendre/.

Lieutier, F., YART, A., and Salle, A. 2009. Stimulation of tree defenses by ophiostomatoid fungi can explain attack success of bark beetles on conifers. Ann. Forest Sci. 66:801-823.

Llusià, J. and PeÑUelas, J. 1998. Changes in terpene content and emission in potted Mediterranean woody plants under severe drought. Can. J. Bot. 76:1366-1373.

McDowell, N., Pockman, W. T., Allen, C. D., Breshears, D. D., Cobb, N., Kolb, T., Plaut, J., Sperry, J., West, A., Williams, D. G., and YePEZ, E. A. 2008. Mechanisms of plant survival and mortality during drought: Why do some plants survive while others succumb to drought? New Phytol. 178:719-739.

Miller, D. R. and Borden, J. H. 1990. $\beta$-Phellandrene: Kairomone for pine engraver, Ips pini (Say) (Coleoptera: Scolytidae). $J$. Chem. Ecol. 16:2519-2531.

Moeck, H. A. and Simmons, C. S. 1991. Primary attraction of mountain pine beetle, Dendroctonus ponderosae Hopk. (Coleoptera: Scolitidae), to bolts of lodgepole pine. Can. Entomol. 123:299-304.

Nebeker, T. E., Schmitz, R. F., Tisdale, R. A., and Hobson, K. R. 1995. Chemical and nutritional status of dwarf mistletoe, armillaria root rot, and comandra blister rust infected trees which may influence tree susceptibility to bark beetle attack. Can. J. Bot. 73:360-369.

Ninnemets, Ü., Reichstein, M., Staudt, M., Seufert, G., and TENHUNEN, J. D. 2002. Stomatal constraints may affect emission of oxygenated monoterpenoids from the foliage of Pinus pinea. Plant Physiol. 130:1371-1385.

OKSANEn, j., Blanchet, F. G., Kindt, R., Legendre, P., O'Hara, R. B., Simpson, G. L., SÓlymos, P., STEVENS, M. H. H., and WAGNER, H. 2010. vegan: Community ecology package. $\mathrm{R}$ package version 1.17-4. http://CRAN.R-project.org/package=vegan.

PAuly, G. and VON RUdolfF, E. 1971. Chemosystematic studies in the genus Pinus: the leaf oil of Pinus contorta var. latifolia. Can. J. Bot. 49:1201-1210.

Pitman, G. B., Vité, J. P., Kinzer, G. W., and Fentiman JR., A. F. 1968. Bark beetle attractants: trans-Verbenol isolated from Dendroctonus. Nature 218:168-169.

Pureswaran, D. S., Gries, R., and Borden, J. H. 2004a. Quantitative variation in monoterpenes in four species of conifers. Biochem. Syst. Ecol. 32:1109-1136.

Pureswaran, D. S., Gries, R., and Borden, J. H. 2004b. Antennal responses of four species of tree-killing bark beetles (Coleoptera: Scolitidae) to volatiles collected from beetles, and their host and nonhost conifers. Chemoecology 14:59-66.

R DeVelopment CoRe TeAm 2010. R: A language and environment for statistical computing (version 2.12.0). R Foundation for Statistical Computing, Vienna, Austria. URL http://www.Rproject.org.

RAFFA, K. F. and Berryman, A. A. 1982. Gustatory cues in the orientation of Dendroctonus ponderosae (Coleoptera: Scolytidae) to host trees. Can. Entomol. 114:97-104.

RAFFA, K. F. and SMALLEY, E. B. 1995. Interaction of pre-attack and induced monoterpene concentrations in host conifer defense against bark beetle-fungal complexes. Oecologia 102:285-295.

RafFa, K. F., Aukema, B. H., Erbilgin, N., KlepziG, K. D., and WALLIN, K. F. 2005. Interactions among conifer terpenoids and bark beetles across multiple levels of scale: An attempt to understand links between population patterns and physiological processes. Recent Adv. Phytochemistry 39:79-118.

REID, R. W., WhitNEY, H. S., and Watson, J. A. 1967. Reactions of lodgepole pine to attack by Dendroctonus ponderosae Hopkins and blue stain fungi. Can. J. Bot. 45:1115-1126.

Rice, A. V., ThormanN, M. N., and LANGOR, D. W. 2007. Mountain pine beetle associated blue-stain fungi cause lesions on jack pine, lodgepole pine, and lodgepole $\mathrm{x}$ jack pine hybrids in Alberta. Can. J. Bot. 85:307-315.

Robinson, D. A., Jones, S. B., Wraith, J. M., OR, D., and FrIEDMAN, S. P. 2003. A review of advances in dielectric and electrical conductivity measurement in soils using time domain reflectometry. Vadose Zone J. 2:444-475.

Rudinsky, J. A., Morgan, M. E., Libbey, L. M., and Putnam, T. B. 1974. Antiaggregative-rivalry pheromone of the mountain pine beetle, and a new arrestant of the southern pine beetle. Environ. Entomol. 3(1):90-98.

RYKER, L. C. and LiBBEY, L. M. 1982. Frontalin in the male mountain pine beetle. J. Chem. Ecol. 8:1399-1409.

SAFranyiK, L., CARroll, A. L., RÉgnière, J., LANGOR, D. W., Riel, W. G., Shore, T. L., Peter, B., CoOke, B. J., Nealis, V. G., and TAYLOR, S.W. 2010. Potential for range expansion of mountain pine beetle into the boreal forest of North America. Can. Entomol. 142:415-442.

Semiz, G., Heijari, J., IsiK, K., and Holopainen, J. K. 2007. Variation in needle terpenoids among Pinus sylvestris L. (Pinaceae) provenances from Turkey. Biochem. Syst. Ecol. 35:652-661.

SHARKEY, T. D. 1991. Stomatal control of trace gas emissions, pp 335339, in T. D. Sharkey, E. A. Holland, and H. A. Mooney (eds.), 
Trace Gas Emissions by Plants. Academic Press, San Diego, California.

Shrimpton, D. M. and Watson, J. A. 1971. Response of lodgepole pine seedlings to inoculation with Europhium clavigerum, a blue stain fungus. Can. J. Bot. 49:373-375.

StURGEON, K. B. 1979. Monoterpene variation in ponderosa pine xylem resin related to western pine beetle predation. Evolution 33:803-814.

TARDiEU, F. and SimonneaU, T. 1998. Variability among species of stomatal control under fluctuating soil water status and evaporative demand: modeling isohydric and anisohydric behaviours. $J$. Exp. Bot. 49:419-432.

TKACZ, B. M. and SCHMITZ, R. F. 1986. Association of an endemic mountain pine beetle population with lodgepole pine infected by armillaria root disease in Utah. USDA For. Serv. Res. Note INT-353.

Turtola, S., Manninen, A.-M., Rikala, R., and Kainulainen, P. 2003. Drought stress alters the concentration of wood terpenoids in scots pine and norway spruce seedlings. J. Chem. Ecol. 29:1981-1995.
VIDACOVIĆ, M. 1991. Conifers: Morphology and Variation. Graficki Zavod Hrvatske, Zagreb, Croatia.

WALLIN, K. F. and RAFFA, K. F. 1999. Altered constitutive and inducible phloem monoterpenes following natural defoliation of jack pine: Implications to host mediated interguild interactions and plant defense theories. J. Chem. Ecol. 25:861-880.

Williams, D. W. and LieBhold, A. M. 2002. Climate change and the outbreak ranges of two North American bark beetles. Agr. For. Entomol. 4:87-99.

[www.for.gov.bc.ca] British Columbia. Ministry of Forests, Lands and Natural Resource Operations. http://www.for.gov.bc.ca/hfp/ mountain pine beetle/Updated-Beetle-Facts_Mar2010.pdf

YAMAOKA, Y., SWANSON, R. H., and HIRATSUKA, Y. 1990. Inoculation of lodgepole pine with four blue-stain fungi associated with mountain pine beetle, monitored by a heat pulse velocity (HPV) instrument. Can. J. Forest Res. 20:31-36.

Zavarin, E., Critchfield, W. B., and SnajBerk, K. 1969. Turpentine composition of Pinus contorta $\times$ Pinus banksiana hybrids and hybrid derivatives. Can. J. Bot. 47:1443-1453. 